\title{
SUSTAINABLE FISHERIES IN SOUTHEAST ASIA ${ }^{1}$
}

\author{
Melda Kamil Ariadno ${ }^{2}$
}

\begin{abstract}
Fisheries activity has increased significantly in number. As a result, we might see high investment in fisheries is due to the high demand for fish and fisheries products. Therefore, marine resources as well as other living resources are at risk in being harmed by excessive fisheries activities, for example: the use of trawl.

Indonesia, as a Maritime State, need to impose sustainable fisheries because the principle of utilizing sustainable fisheries resources as adopted in the Law on Fisheries (Law No. 31 Year 2004 as amended by Law No. 45 Year 2009) to control fishery activities.Fishery activities are regulated not only by the Law on Fisheries but also international regulation adopted worldwide such as the Code of Conduct for Responsible Fisheries (CCRF). CCRF was prepared to include primary principles to elaborate the mechanism of fishery activities which is designated not to cost harmful damages in fisheries activities. CCRF is also accompanied by several technical guidelines that provide certain procedures to be applied to (1) fishing operations; (2) the precautionary approach as applied to capture fisheries and species introductions; (3) integrating fisheries into coastal area management; (4) fisheries management; (5) aquaculture development; and (6) inland fisheries. Consequently, CCRF is intended to cover any kind of fishery anywhere in the world not just marine capture fisheries, but also freshwater fisheries as well as aquaculture both marine and freshwater aquaculture.

Excessive fishery activities would then not be harmful if Indonesia is willing to impose regulation which is significantly and effectively to manage these kind of fishery activities. Along with the fact that Indonesia is recognized as a Marine State, there is no reason to hold back in addressing this situation.
\end{abstract}

Keywords: CCRF, excessive, fisheries activity, sustainable

\section{Introduction}

The high investment in fisheries due to high demand for fish and fishery products all over the world has caused development of modern fishing fleets with enhanced processing factories. Unfortunately the depletion of fisheries resources is the certain threat if the exploitation has been done without proper

\footnotetext{
${ }^{1}$ Based on the researches made by the writer as part of teamwork in : (1) Preliminary Review of Legislative And Regulatory Framework in Relation to Bycatch Reduction in The Shrimp Trawl Fishery in Indonesia, Technical Cooperation Programme (Ep/Glo/201/Gef), Food And Agriculture Organization of The United Nations, 2006. (2) Reviewing and Enhancing Bycatch Reduction and Change Management of Trawl Fisheries in Indonesian Through Comprehensive Regulations, cooperation between Food and Agriculture Organization (FAO) of The United Nations and Ministry of Marine Affairs and Fisheries, 2007.

${ }^{2}$ Lecturer in International Law on Faculty of Law, University of Indonesia. Lecturer at international Law, Faculty of Law, University of Indonesia. Obtained Bachelor of Law Degree (S.H.) from University of Indonesia (1992), Magister of Law Degree (LL.M.) from University of Washington (1995), and a Doctor of Philosophy Degree (Ph.D) from University of Washington (2011).
} 
management and anticipation. The long-term sustainability ${ }^{3}$ of fisheries has been threatened by over-exploitation, modifications of ecosystem as well as conflicts on management. As an expected answer FAO recommended new approaches to fisheries management by embracing the conservation and environmental considerations, as well as social and economic approaches. In the Nineteenth Session of the FAO Committee on Fisheries (COFI) in March 1991, "FAO had been asked [by the COFI] to develop the concept of responsible fisheries and elaborate a Code of Conduct to foster its application"4.

The International Conference on Responsible Fishing was held by FAO in collaboration with the Government of Mexico in Cancun, May 1992, which formed the Declaration of Cancun that brought to the attention of the United Nations Conference on Environment and Development (UNCED) Summit in Rio de Janeiro, Brazil, in June 1992. The preparation of the Code of Conduct for Responsible Fisheries (CCRF) had been carried out by FAO in collaboration with the other international organizations and non-governmental organization (NGO). CCRF was made in conformity with other international rules applied in the arena of international law of the sea, as reflected in the 1982 UNCLOS and its implementing/related agreements ${ }^{5}$, and in the light of the 1992 Declaration of Cancun and the 1992 Rio Declaration.

In the Twenty-eight Session of the COFI, CCRF had eventually adopted in Resolution 4/95 on 31 October $1995^{6}$. Although CCRF is voluntary, many of its principles, such as the precautionary principles and the concept of Ecosystem Approach to Fisheries (EAF) actually have been enshrined in the international laws that have been embodied in several international measures, including: the 1972 World Conference on Human Environment; the 1982 United Nations Convention on the Law of the Sea; Agenda 21 of the 1992 United Nations Conference on Environment and Developments; The 1992 Convention on Biological Diversity; and The 1995 UN Fish Stocks Agreement

Such principles also recognized in the Political Declaration and the Plan of Implementation in relation to capture fisheries, adopted in The Johannesburg Declaration of the World Summit on Sustainable Development (WSSD) that held

\footnotetext{
${ }^{3}$ One of sustainable development paradigms in fisheries is the sustainable utilization of the marine fisheries resources. This paradigm actually requires states to apply 'precautionary approach' in fishing management within its jurisdiction as well as in the high seas.

Sustainable development itself is defined as “... development that meets the needs of the present without compromising the ability of future generations to meet their own needs". Definition is given by the Brundtland Commission at the 1987 Report of the World Commission on Environment and Development. This concept itself has not yet become a customary international law, but it has been followed and quoted in always every movement in environmental protection and conservation, some scholars indeed argued that is well on its way to become a customary international law. Susan J. Buck, The Global Commons: An Introduction, 76 (1998). See also http://www.johannesburgsummit.org/html/basic_info/unced.html
}

${ }^{4}$ FAO Fisheries Department, The Ecosystem Approach to Fisheries," FAO Technical Guidelines for Responsible Fisheries, No. 4, Suppl.2., Rome, FAO, 1 (2003).

${ }^{5}$ Including the Agreement for the Implementation of the Provisions of the United Nations Convention on the Law of the Sea of 10 December 1982 Relating to the Conservation and Management of Straddling Stocks, 1995 (1995 UN Fish Stocks Agreement) and the Agreement to Promote Compliance with the International Conservation and Management Measures by Fishing Vessels on the High Seas, 1993 (1993 FAO Compliance Agreement).

${ }^{6}$ CCRF consists of five introductory articles, one article on general principles and six thematic articles. See http://www.fao.org/documents/show_cdr.asp?url_file=/DOCREP/005/v9878e/v9878e00.htm 
in Johannesburg, South Africa, 2002. The Declaration acknowledged to ${ }^{7}$ :

[develop] and facilitate the use of diverse approaches and tools, including the ecosystem approach, the elimination of destructive practices, the establishment of marine protected areas...and the integration of marine and coastal areas into key sectors (31c).

The United Nations Environment Programme (UNEP) as implementing agency and the Food Agriculture Organization (FAO) as executing agency have launched the Project named "Reduction of Environmental Impact From Tropical Shrimp Trawling Through the Introduction of By-Catch Reduction Technologies and Change of Management" (EP/GLO/201/GEF) as part of movement toward achieving sustainable fisheries. This project has been asked by certain tropical countries including Indonesia. As stated in the summary of the Project, shrimp exploitation by tropical trawl fisheries has generated significant amounts of nonshrimp by-catch. While in some countries, by-catch has become an important source of income and contributes to food supply, there a lot of by-catch, including fish and turtle are discarded at sea. This practice has been a threat to the sustainable production of fish and to the biodiversity of marine living resources (mostly are turtles) in a fishing area. The Project aims to introduce appropriate fishing technologies and practices that could reduce the capture of juveniles and other by-catch in certain countries in various regions. Hence these practices and technologies then hopefully would be adopted by other shrimp fishing countries also experiencing by-catch problems. In the end the success of the Project will increase fish production and conservation of biodiversity as well as improving shrimp trawling as one of source of income in developing countries.

\section{Sustainable Fisheries Management}

CCRF stipulates certain principles to be adopted voluntarily by the FAO Member States in their own national fisheries management policy. One of the activities which cause the depletion of fisheries resources is by-catch phenomenon. Thus CCRF has carefully addressed this issue and spelled out the major principles in upholding by-catch reduction.

Fish retained by fishing gear can be distinguished into at least three groups; these are catch of target species, by-catch and discards. The target species is specific fish groups that are expected by fishermen or fishing companies. Therefore, they are prepared with specific fishing gear and method. To fishing companies, target species is clearly defined because they have to make sure their commitments to their product buyers will be fulfilled. Their products are usually well defined with clear description of quality and quantity. These companies will usually focus to achieve their target of production and sales. They normally direct their fishing fleets with clear target, not only target species but also quality and quantity of the catch. Therefore, fishing companies are likely not interested with by-catch, but their fishermen are likely as long there is sufficient time to handle the target species and availability of space in fish holds to store their personal collection ${ }^{8}$.

\footnotetext{
${ }^{7}$ See FAO, Note 12 at 4.

${ }^{8}$ See Note 1.
} 
In Indonesia, for instance, not all by-catch are kept onboard (by fishermen), the rest will be returned to the sea as discards. It is well known in trawl fisheries targeting shrimps, where the proportion of by-catch far exceeds the proportion of the shrimps. Therefore, discards become one of big issues in the trawl fisheries, especially that is conducted by fishing companies operating large sized trawlers. The issues of by-catch and discards from trawl fisheries conducted by small scaled fisheries are significantly different from the trawl fisheries conducted by industrial fishing companies. Shrimps are the most expected catch among small-scale trawl fishermen. Some small scale fishermen may have no specific target species. They are not confident if they will catch the target because population of the target species is already at low level. To them, any catch is valuable and worth to be retained. In contrast to shrimps targeting trawling, the fish trawls consequently produce less by-catch since their catch is dominated by their targets which are multi-species of finfish. Certainly if they accidentally catch some shrimps, they will retain the by-catch on-board. Fishermen are likely concerned when the catch is dominated by small-sized fish individuals of no market value . $^{9}$

The following CCRF's principles are relatively related to reducing bycatch practices ${ }^{10}$ :

1. General Principles

a. Fisheries management should promote the maintenance of the quality, diversity and availability of fishery resources for present and future generations;

b. Conservation and management decision should be based on the best scientific evidence available;

c. States and fisheries management organization should apply a precautionary approach;

d. Selective and environmentally safe fishing gear and practices should be developed;

e. States should ensure compliance with and enforcement of conservation and management measures;

f. States should effectively control their fishing vessels;

g. States should cooperate at sub-regional, regional and global level through fisheries organizations to promote conservation and management;

h. States should ensure that decision making process are transparent and efficient;

i. States should cooperate to prevent dispute and resolve any dispute in peaceful manner;

j. States should promote awareness of responsible fisheries through education and training;

2. Fisheries Research

States should recognize that sound scientific basis is needed to support responsible fisheries policy, thus the research facilities should be available as well as the human resources.

\footnotetext{
${ }^{9}$ Ibid.

${ }^{10}$ See http://www.fao.org/documents/show_cdr.asp?url_file=/DOCREP/005/v9878e/v9878e00. 


\section{Regional and International Cooperation}

States should enhance the collaboration with the regional fishery organization particularly when they fish the same stocks, so that the dispute could be avoided and the better management could be achieved.

Hence CCRF urges states to implement comprehensive and integrated national fisheries policy to achieve a healthier and improved fish stocks, so that it could meet the need of the present as well as the future generations. The principles are compatible with the movement of reducing by-catch, because bycatch not only will harm the sustainability of fish stock but also will damage the biodiversity of marine creatures.

CCRF has actually been adopted in many fisheries management especially through the FAO programs which widely introduce CCRF to its member states, including in Indonesia. Although it remains unclear whether they are truly applied in effective mechanism of fisheries management or just adopted as a policy issue that means many states agree to those principles but not yet well implement those in their management tools.

CCRF is also accompanied by several technical guidelines that provide certain procedures to be applied to (1) fishing operations; (2) the precautionary approach as applied to capture fisheries and species introductions; (3) integrating fisheries into coastal area management; (4) fisheries management; (5) aquaculture development; and (6) inland fisheries. Thus, CCRF is intended to cover any kind of fishery anywhere in the world not just marine capture fisheries, but also freshwater fisheries as well as aquaculture both marine and freshwater aquaculture ${ }^{11}$.

\section{Indonesian Practices}

Indonesia is considered one the richest marine biodiversity areas in the world, its fisheries represent more than $37 \%$ of the world species ${ }^{12}$. Indonesia has the second longest coastline in the world after Canada and approximately 17, 508 islands. This geographical condition means Indonesia has enormous resources of marine fisheries as well as the opportunity to develop fishing industries ${ }^{13}$. The challenge for Indonesia is how to manage the exploitation of marine fisheries in order to meet population demand as well as market demand, without causing depletion of fisheries resources ${ }^{14}$.

The most crucial fishing activity in Indonesia related to sustainability is trawl fisheries either fish and shrimp trawling. Trawling has been practiced

\footnotetext{
${ }^{11}$ Ibid.

12 Maurice Knight and Kem Lowry, "Institutional Arrangements for Decentralized Coastal Management in Indonesia", at 1, paper presented at "The Challenges of Public for Sustainable Ocean and Coastal Development", Global Conference on Oceans and Coasts at Rio, December 10, 2001, Paris, France.

${ }^{13}$ It is estimated that between $65 \%$ - $95 \%$ of the Indonesian population are living near the coasts (within $100 \mathrm{~km}$ of the coast), and $80 \%$ of those depend on the fisheries resources, either fishing or mariculture. Two third of animal-based protein uptake in Indonesia is from fish products. Ibid at 2.

${ }^{14}$ Indonesia inshore/coastal fisheries (usually demersal fish) is primarily to meet population consumption, but Indonesia also engages offshore fishing (pelagic fish, such as tuna and tuna-like) which is mainly for exporting, mostly to Japan and Europe.
} 
in Indonesia for a long time, several regulations have been enacted to govern this practice in order to preserve the resources and conserve the marine environment ${ }^{15}$.

\section{A. Indonesian Policy}

\section{National Law on Trawl}

The use of trawl in Indonesian fisheries management area is banned since 1980 by the Presidential Decree No. 39 Year 1980 on Trawl Net Elimination. The Elimination was done step by step, until 1982 when Presidential Instruction No.11 Year 1982, recognized January $1^{\text {st }} 1983$ as the date for which there should be no fishing ship using trawl net in Indonesia. The basic consideration of Presidential Decree No. 39 Year 1980 was for the conservation of fishery resources to support the increase of the production by the traditional fisherman and prevent the social tension. In 1982 however was launched the exception of trawl usage, that was the use of shrimp's dragnet as trawl net substitute was allowed in the sea water of Kei Islands, Tanimbar, Aru, Irian Jaya, and the Arafuru's sea with a coordinate border $130^{\circ}$ BT to the east, this action was driven by the existing Japanese investor on shrimp fishery in those areas.

The use of Shrimp's dragnet which was regulated in Presidential Decree No. 85 Year 1982 determines that:

- permits to use the shrimp's dragnet are given to the fishing companies which had the license to fish shrimp in the waters mentioned above;

- the number of fishing ships licensed to use shrimp's dragnet should not inhibit the support capacity of local shrimp resources;

- permission to use the shrimp's dragnet is given by the Ministry of Agriculture;

- fishing companies which are licensed to use the Shrimp's dragnet have an obligation to give by-catch result to the fishing state company for public use;

- to increase the efficiency of using Shrimp's dragnet, joint research by the Research and Technological Implementation Board (BPPT), Fisheries Research Centre (Badan Penelitian Perikanan Laut), and Directorate General of Fishery of Department of Agriculture is conducted;

- with regard to sea area not included in Article 1, Presidential Decree No. 39 Year 1980 and Presidential Instruction No.11 Year 1982 are applied where the use of Shrimp's dragnet is not allowed;

- fishing companies which breach the Presidential Decree should lose their license;

\footnotetext{
${ }^{15}$ Trawler fleet (1996) of 431 vessels from 19 to 849 GT. Three types of trawl riggings are used: single trawl towed from the stern of the vessel; outrigger twin trawls (two trawls); and outrigger quad trawls (four trawls). According to Presidential Decree No085/1982 all units should be equipped with a bycatch efficiency device (BED), which is a modified form of a turtle-excluder device (TED). The law of 1982 restricts trawling for shrimp to the Arafura Sea (eastern Indonesia). The shrimp catch from that area was approximately 20000 tonnes, in 1996, which is $10 \%$ of the total catch in that area. The remaining catch includes landed as well a discarded by-catches, mainly of fish. Generally, the shrimp/by-catch ratio is 1 to 8-15. The yield from shrimp has more or less levelled off over a long period of observation, but fluctuation is observed from year to year. The catches of demersal and pelagic fish are increasing slightly. The estimate for 1998 is around 200000 tonnes of by-catch, of which 170000 tonnes were discarded. Nearly 2/3 of the total landings consist of fish. See Document of the Project "Reduction of Environmental Impact From Tropical Shrimp Trawling Through the Introduction of By-Catch Reduction Technologies and Change of Management" (EP/GLO/201/GEF).
} 
- the Minister of Agriculture further regulates the implementation of the Presidential Decree;

- the Decree would apply from the designated date (December $24^{\text {th }} 1982$ ).

Following this Presidential Decree then was announced the Decree of Ministry of Agriculture No. 930/Kpts/Um/12/1982 concerning the implementation of Presidential Decree No. 85 Year 1982 in December $27^{\text {th }} 1982$ and General Director of Fishery is empowered to determine the construction of shrimp's dragnet by Director General Decree No. IK.010/S3.8075/82 on The Shrimp Trawl Net Construction (December 31 ${ }^{\text {st }}, 1982$ ) are:

Among other regulations which related to trawl management in Indonesia

- Minister of Agriculture Decree No. 503/Kpts/Um/7/1980, the first steps to implement the elimination for the use of trawl net. This Decree completed Presidential Decree 39 Year 1980 and gives detail definitions of Trawl Net. Based on this Minister of Agriculture Decree, trawl net is a kind of fish net in the shape of bag and being dragged by ship and using beam or otter board and net dragged by two ships. This decree also gives explanation about the kind of trawl net, such as: pukat harimau, pukat tarik, tangkul tarik, jarring tarik, jaring trawl ikan, pukat Apollo, and pukat langgai. There is also description that shrimp net has the same construction with trawl net however shrimp net has by-catch excluder devices.

- Minister of Agriculture Decree Number 694/Kpts/Um/9/1980 on Limitation of Fishing Zone for Business of Trawl Fisheries. This Decree establishes the boundaries of Indonesian fishing zone which are forbidden for fishing operation by trawl net.

- Minister of Agriculture Decree No. 542/Kpts/Um/6/1981 on Determination Number of Trawl Ships in the Province Out side Java, Bali, and Sumatera. This Decree governs the number of Trawl ship in The Province outside Java, Bali, and Sumatra and the operation of those ships have to follow the direction and conduct consultation with Director General of Fisheries.

- Minister of Agriculture Decree No. 392 Year 1999 on Fishing Zone. This Decree determines closed zone for ships using Trawl net and states the kind of Trawl Net that cannot be used.

- Ministry of Agriculture Decree No. 770/Kpts/IK.120/10/96 about The Usage of Fish Trawl Net in IEEZ India Ocean Western Sumatera and Surrounding D.I. Aceh

- Ministry of Agriculture Decree No. 1039.1/Kpts/IK.120/10/99 on The Change of The Ministry of Agriculture Decree No. 770/Kpts/IK.120/10/96 on The Usage of Fish Trawl Net in IEEZ India Ocean Western Sumatra and Surrounding D.I. Aceh

- Directorate General of Fisheries Decree No. 868/Kpts/IK.340/II/2000 -The Construction of Fishes Separating Devices (API/TED) and Fishing Ground for Shrimp Trawl Net (February 10th 2000)

The use of trawl is indeed considered as illegal in Indonesia since 1980, except those where are permitted under the Presidential Decree No. 85 Year 1982 and other regulations. It is however difficult to be implemented, since 
trawl is unarguably the most efficient and effective means to catch shrimp and other bottom species. As also can be seen in those above regulations, several exceptions have been made toward Presidential Decree No. 39 Year 1980, based on the reasons of foreign investment, the need to utilize EEZ and there are certain areas in Indonesian that still could be exploited by trawl net. Unfortunately those exceptions are considered unsatisfied, the result undeniably is the legal smuggling done by fishermen all over Indonesia, especially in the areas where it is forbidden to use trawl. Fishermen make the substitute of trawl and call it with different name (jaringarad, lamparadasar, cantrang, etc.) so that it could be used legally, it has to be acknowledged however that such tool has similar function with trawl and could be categorized as trawl. This condition has been happening until present time.

It has to be admitted that Indonesia has actually had quite comprehensive regulations which govern fisheries management. The Law No. 31 Year 2004,as amended by The Law No. 45 Year 2009 which replaced The Law No. 9 Year 1985, has stipulated almost all relevant principles and management tools which are believed compatible with national needs and could be implemented effectively in the fishing activity. This new law has clearly identified that fisheries management in Indonesia has to achieve continuous productivity (article 1 point 7) and optimal as well as sustainable use of fisheries resource (article 6 paragraph 1). In achieving this aim, the adat law and local knowledge should be observed, and the role of local community should be taken into account (article 6 paragraph 2 ).

Below are other articles that are embedded in the Law No. 31 Year 2004 which could be related to trawl management:

\section{Article 7 paragraph 1 (c \& f):}

Minister of Fisheries may declare limitation on every fishing activity. This is to make sure that every person who fishes in the Indonesian fisheries management area also maintains sustainable fisheries. These limitations are: species of fish which is allowed to catch, maximum quantity of the catch, and tools allowed to be used in fisheries.

\section{Article 7 paragraph $\mathbf{j}, \mathrm{h}, \mathrm{n}$ and $\mathrm{p}$ :}

Minister of Fisheries states fishing ground, lanes, and catch time and fishing season. He also regulates vessel monitoring system, the prevention of pollution and damage of fisheries resource and its environment, as well as fisheries reserves.

\section{Article 8:}

This section prohibits any person to catch fisheries by any materials and means which could harm sustainability of fisheries resource as well as its environment in Indonesian fisheries management area.

\section{Article 9:}

Every person and every vessel is prohibited to use any kind of fisheries tools that is unsuitable with determined size, unsuitable with standard and requirement for certain tool, and prohibited 


\section{Article 13:}

In managing fisheries resources there should be effort to conserve ecosystem, fisheries species and fish genetic.

\section{Article 26:}

Every person who involves in fisheries effort must have a license to engage in fisheries activities, except those who are considered as small scale fishermen.

\section{Article 46:}

The Government develops information system and fisheries statistical data.

\section{Article 60:}

Government is mandated to empower small scale fishermen, while the definition of small scale fishermen is given in article 1 point 11, as fisherman who catches fish as his livelihood to fulfill his daily needs.

\section{Article 61:}

Small scale fisherman is free to fish in any area within Indonesian fishing management area.

It is clear that every fishing effort has to be in accordance with the Law No. 31 Year 2004 and any implementing regulations, including those laws which are never revoked such as Presidential Decree No. 39 Year 1980. Learning those above regulations, trawl is obviously forbidden to use in Indonesian fishing management area unless in the area where exception to that are given. Unfortunately the law has not been followed due to the needs of fishermen to obtain the optimum result in fishing, and the relatively weak legal enforcement. This study has come to conclusion that there is legal smuggling toward Presidential Decree No. 39 Year 1980 and that law has not been effectively implemented ever since it was enacted.

\section{Regional Law}

Any law should also consider the autonomy law as embedded in the Law No. 32 Year 2004, which gives jurisdiction to govern fisheries resources within regional territory to regional government (article 18). Therefore in this study the local opinions on law concerning trawl have been identified, and the sample of regional as well as the local law have been collected and analyzed as can be seen below:

Legal issues on trawl:

(1) The use of trawl

1) Many fishermen use trawl to catch fish even though it is forbidden;

2) Trawl is used widely in territorial sea of Indonesia although it is prohibited by Presidential Decree 39/1980;

3) There are two kinds of targeted species in Indonesian trawl fishery, those are shrimp and other fishes; 
4) The prohibition of trawl has a direct effect to fishermen life, since trawl is the most effective and efficient mean to catch shrimp and any bottom fish;

5) The fishermen invent other devices which have similar function with trawl and call it by different name, this could be identified as legal smuggling;

6) Many foreign vessels engage illegal fishing in Indonesia using trawl, this condition is unfair toward the local fishermen;

7) Trawl net is the most effective equipment to catch fish although it is harm to the marine environment. Thus there is a contradiction between the need of fishermen to fulfill their daily needs and the sustainable fish stock and marine environment.

8) Government has tried to replace trawl with other gear, but there is no gear which could function as effective as trawl;

9) Trawl is commonly used among small scale fishermen, with 5 GT fishing vessel and operating in one day fishing;

10) There are big modern companies of shrimp trawl operating in Eastern Part of Indonesia as regulated by The Presidential Decree No. 85 Year 1982.

11) There are quite large trawlers which sometimes operating in Zone 1 (between 0-3 nautical miles);

12) The demand of shrimp is large, in some regions the catch has exported to neighboring country such as Malaysia and Singapore;

13) There are certain fishermen association which has self divided themselves to operate within certain zones based on the size of the trawl vessel.

(2) The impact of trawl usage

1) Fishermen realize that trawl is actually harmful to the environment, but there is no other gears which as effective as trawl;

2) Trawl has caused a lot of social conflict among fishermen, especially between trawler and non trawler;

3) Trawl is harmful if used by big fishing vessel, while the small trawl ship is relatively not harmful;

4) The use of Shrimp Trawl in the east of territorial sea of Indonesia has been misconduct. Fishermen have entered Zone I to catch shrimp which has resulted conflict of interest with traditional fishermen. Their Trawl net has actually been equipped by Fish Excluder Device (API), however they often remove that device while catching on the sea because it could destruct the quality of shrimp and avoid the big fish to be caught;

5) Economically, the use of trawl net gives benefit because of its effectiveness to catch fish but it is not sustainable for fish stock.

(3) The Perception on Existing Regulations and Law Enforcement

1) The periodical socialization on trawling regulation has been done since 1980. However it is not effective since it is against the need of fishermen; 
2) There is unclear definition on trawl, thus it is easy to make modification of tool which can be replacing the function of trawl;

3) There should be a reliable data on stock assessment as evidence to prohibit trawl in certain area;

4) There must be clear regulation if the use of Trawl net is allowed, e.g. :

a. Regulations concerning fishing zone for fishermen in order to avoid conflict;

b. The use of Fish Excluder Device (API) is strictly implemented;

c. There should be clear difference between fish catch or shrimp catch;

5) There should be an intensive socialization of regulation and punishment, which could be done through:

a. Public advice on the drafting of regulation;

b. Public hearing before the regulation is entry into force in order to know the public respond whether they are ready or not if the regulation is implemented.

c. Enhance socialization to public, e.g.: there is small banner which is plugged in strategic public places before the regulation is entry into force;

d. Monitoring on effectiveness of socialization before the entry into force of regulations.

6) Synchronization of national regulations which regulate delimitation of each region, for instance between the rules on regional territory and the fishing zone ${ }^{16}$;

7) Punishment must be implemented strictly, consistent, and applicable to everyone. There should be regulation in regional level, both provincial and district level;

8) There must be good law enforcement to every person that breach the limitation made in the regulation;

9) The Presidential Decree No. 39 Year 1980 is not conform with the needs of traditional/small scale fishermen, there should be overview toward it;

10) Regional Autonomy has caused conflict because of unclear regulation on the use of trawl net as well as the exclusion principle of foreign fishermen ${ }^{17}$.

(4) By-catch

1) There are two different characteristics in different part of Indonesian water. In western part of Indonesia, almost there is no by-catch and most of fish catch has economic value. The problem is only on how to release the juvenile so that there would be an availability and sustainability of fish stock. Different case however is settled in eastern part of Indonesia, where the main catch is shrimp, which are operated by big fishing company located in Sorong. There is a lot of by-catch

${ }^{16}$ Under regional autonomy law, province could exercise its jurisdiction upon up to 12 miles sea territory while district could impose its jurisdiction upon $1 / 3$ of province's sea territory. On the other hand, there is fisheries regulation which divides sea territory into three fishing zone (0-3 and 3-6 as Zone I, 6-12 as Zone II and beyond 12 miles as Zone III) See Law No. 32 Year 2004 and Minister of Agriculture Decree No. 392 Year 1999 on Fishing Zone.

${ }^{17}$ Could foreign fisherman come to fish in certain local area? Under The Law No. 31 Year 2004 on Fisheries, small scale fishermen could fish anywhere in Indonesian water. 
in their operation area, some of the by-catch which having economic value will be returned to the port, or sold at site to the fishing collector, yet many of them are discarded to the sea;

2) Equipment of fishing operation is modification of trawl net. The shrimp trawl using in eastern part is equipped by TAD as imposed by existing regulation, even though is often removed while fishing, yet the other modified trawl and fish net are not equipped by any by-catch technical devices;

3) Sometimes trawl catches marine turtle by accident, it is usually immediately released, hence most of it are harmed by the time it is returning to the sea. There are specific migration area of turtle;

4) There is no local regulation concerning by-catch except one regional regulation in Sorong which governs that bycatch from shrimp trawl cannot be discarded on the sea, by-catch should be brought back ashore and sold to the processing company. This regulation is however not effective anymore, since the designated company which collected the by-catch is collapsed.

(5) The expectation on trawl management

1) The regulation that prohibits trawling must be reexamined whether it is in conformity with the need of fishermen and national interest;

2) There should be a limitation on use of trawl;

3) There should be strict license for fishermen. The problem is that traditional fishermen in small scale do not have to obtain any license for their activity;

4) The necessary consideration in managing trawl fishery:

a. The Allowable time;

b. Delimitation of allowable fish catch zone;

c. Type of ship and fish catch devices;

d. Socialization of regulations and punishment;

e. Consideration on the benefit of fish catch activities; and

f. Consideration on sustainability of fish stock.

5) There should be commitment and conducive communication between stakeholders;

6) The distance between operating ship should be governed, to avoid any conflict among them;

7) Fishing zone should be divided based on type and size of ship;

8) Local knowledge and local law could be utilized to avoid conflict between fishermen;

9) There should be special compensation program to reduce fishermen (trade off program);

10) There must be reduction on:
a. number of ship;
b. time of fishing operation (open and close season);
c. dividing time of fishing operation among fishermen;

11) There is no income from trawl fishery since it is done illegally, therefore trawl must be appropriately managed in the future;

12) There should be dividing line for trawling vessels and non-trawling vessels; 
13) Government should make a limitation on the quantity of vessels allowed to use trawl fishnet as their tool;

14) Government should determine tax charged on trawling vessels. This tax would be an extra cost which is used to limit vessel using trawl fishnet as their tool;

15) The MMAF should facilitate every legal enforcer. Government should utilize Indonesian Navy, Indonesian Police and Civil Servant Investigator as the key actors in imposing MCS as well as law enforcement;

16) The government must consider how to promote equality and balance between trawl fishermen and non-trawl fishermen;

17) The administration fee to acquire license for a vessel with trawl fishnet to operate should be higher and significant.

18) By-catch should be appropriately governed so it will not harm the operation of trawl, especially big shrimp trawl industry in eastern part of Indonesia. There should be a designated company which will handle the by-catch commercially and effectively.

Local regulations:

(1) Surat Edaran Gubernur No. 523.32/3432/B.4 on Prohibition to Use Trawl Fishnet

(2) Surat Edaran Bupati Kepala Daerah Tingkat II Bengkulu Utara No. 532/0/80/B.4 on The Implementation of Keputusan Presiden No. 39/1980 in Bengkulu

(3) Memorandum of Understanding (MOU) between Head of District Nunukan, Bulungan, Berau, and Mayor of Tarakan concerning Management and Exploitation of Fish Resources in East Kalimantan Border Area, which signed in Balikpapan, on 17 Mei 2003. This MOU regulated several things such as:

- Fish resources exploitation shall suitable with the support capability of their natural resources.

- The license for fishing exploitation is only given to the fishing ship from the District of Nunukan, Bulungan, Berau, and Tarakan City.

- The Issuance of ship license shall be in accordance with national regulation on licensing.

- Fishing tool should be effective and productive and does not damage fish resources and its environment, including trawl. In special cases, the use of certain fishing device is required to be completed with assisting device.

- Specification for fishing device unit will be determined by the Minister of Marine Affairs and Fishery, by considering the existed condition.

(4) Decree of Lurah Muarareja, Kecamatan Tegal Barat No. 523/01/2004 governs that "jaringarad" (trawl) shall not be used in east monsoon, and if that gear is broken, the owner shall not make the replacement. Every conflict arising will be solved by fishermen representative.

Based on above findings, trawl is actually used by fishermen almost everywhere in Indonesian water. The regional government off course has to follow the national law as the supreme law in Indonesia, yet the condition of 
small scale fishermen who are the most users of trawl net have forced regional officers to let the fishermen to use that kind of gear.

\section{B. Various Regional Practices}

Trawling is practiced almost in all Indonesian water, including in territorial sea. In every small medium regional landing port are likely found fishing vessel using trawl as fishing gear, which addressed by different local name such as "lamparadasar/jaringarad/pukat harimau/pukat ikan". Among significant areas which widely practicing this type of fishing are Cirebon, Pekalongan, Tegal,

Some fishermen in Cirebon operate trawls which are locally called jaringarad or jaringarat. The trawl in the area can be easily recognized from wooden otter-boards equipped with cylindrical metal at the bottom edge. However, these fleets will return to Jakarta (MuaraAngke) after fishing in waters off Cirebon and its west-side adjacent district, Indramayu. While in Tegal there are two major fish landing sites which are the TPI at new fishing port and TPI Muara Reja, in the western part of Tegal City. Fishing fleets at the first TPI are dominated by fishing vessels (larger than 15 GT) which are used to operate cantrang. The length of fishing trip of this type of boat is 15-20 days; the fishing ground extends to waters at the border of Java Sea. The second landing site are dominated by smaller fishing boats (about 5-10 GT) which operate jaringarad (similar to the jaringarad of Cirebon). The most interesting practice is however the adoption of local law in Tegal. Community at Muarareja has established local regulation that controls the use of three types of fishing gear, including jaringarad, in the adjacent coastal waters.

The fleets in Bengkulu are dominated by one-day trip small-sized trawlers (less than 5 GT). Their main target species is penaeid shrimps while other organisms, mainly fish, are kept and sold fresh to local fish retailers or processed into dried fish. All catch are well utilized; the by-catch or catch other than shrimps are not discarded since fishermen considers each catch is valuable, either marketable or for their daily consumption. In West Kalimantan, the trawls are operated widely.After the Presidential Decree, the fishers modified their fishing gear into bottom lampara for demersal fishing. As a matter of fact, this gear could be classified of a trawl in term of fishing methods.

The largest fishing base for trawl in Mallaca strait is Belawan. The trawls are commonly called 'pukatikan' since they are officially types of trawls for catching fish in the Indonesia Exclusive Economic Zone. These trawls are operated by large-sized boat, therefore the fishing permits must be obtained from central government. Other mobile fishing gear for catching ground fish are lamparadasar, dogol, cantrang, and jaringarad; these types of fishing gear are grouped under category of seine net or 'pukatkantong'. While in Tarakan the fisheries is dominated by small-scale trawlers of 5 GT; size of larger trawlers are up to 20 GT. The larger trawlers operate trawls locally called "lamparadasar" as described in their fishing permit. Trawler fisheries at Sorong involve fishing companies of industrial scale with foreign investment. Even though the trawlers are equipped with turtle excluder device (TED), but this equipment is used mainly when officials inspected the boats. 


\section{Major Findings}

Based on the above mentioned description, the existing rule on trawl fisheries (i.e., Presidential Decree No. 39 Year 1980) is not effective since trawls are operated in many places regardless the terms of its modification. At the same time, such rule has created significant problem. With expectation in Arafura sea, trawls are not well registered officially, i.e. they are not explicitly listed in regional fisheries statistics. Some of them are considered modifiedtrawls with several names, including jaringarad (seine net for demersal fish) and various local names that are not necessary consistent among places, e.g. cotok. Some trawls can be registered according to type of gear described in local permit prepared by local fishing authority. Therefore, it is not surprising if local and regional fisheries management do not work well because of lack of data.

The poor registration of the trawls mentioned above has some bad implications to fisheries management, both regional and national level, including:

(1) Trawl fisheries are not well regulated fishing.

(2) Demersal fisheries resources are not well managed because trawls generally have significant catch of this type of fisheries resources. Catch of trawls is not recorded properly. Therefore, status of fisheries resources cannot be assessed properly and decisions of fisheries management may be inappropriate.

(3) Fishermen who operate trawls are subject to penalty all the time because they are classified as fishers who operate illegal fishing.

(4) Fisheries authorities (i.e. regional fisheries agencies) are in a dilemma as whether to enforce the existing rule that stops trawl fishing or to allow fishermen who insist to operate the illegal fishing because of their livelihood.

(5) Local governments cannot gain maximum benefit from the trawl fisheries since most benefit will go to a group of people who directly control and under cover the practice of illegal fishing.

(6) Fisheries resources in trawlable area are not utilized by legal-domestic fishing fleets, instead illegal foreign fishing boats.

(7) Many fisheries management measures cannot be implemented since fisheries policies are perceived being inconsistent by fishermen who obey existing regulation. This sentiment will become a big constraint in promoting participatory fisheries management.

The presidential decree has been used intensively by groups of people who advocate social support and opportunity to small scale fishermen operating their boats in narrow strips of coastal waters. The groups include fisheries authorities who realize limitation of carrying capacity of existing fishing areas to accommodate fishermen interests, including trawl fishermen. Therefore, there is a strong polarization of perception or conflict on trawl fisheries which may be prevalent among fishing community in Indonesia.

Those who against the operation of trawls have expressed some complaints or concerns such as: 
(1) trawl operators tend to enter shallow coastal waters of fishing lane 1 because their main targets (penaeid prawns) commonly concentrate in the area.

(2) trawl operators tend to ignore environmental consequences, including excessive fishing.

(3) trawl is more effective and productive to catch demersal fish than other small scale fishing gear.

(4) trawl operators are arrogant, especially when they received unofficial backup.

(5) current system of fisheries management (including fisheries inspectors) has not capacity to control the behavior of trawl fishing fleets.

(6) small scale fishermen is not sufficiently supported by fisheries authority to access and utilize their exclusive fishing area.

From sustainability point of view, the idea of prohibiting trawl fisheries in such places is understandable and should be promoted. In this context, small scale fisheries should be protected from excessive fishing capacity, including unfair competition with trawl fisheries. Current rule on fishing lanes or zones provide clear protection to protect small scale fisheries. Coastal waters nearby coastlines are exclusively allocated to fishermen who operates static fishing gear with non-powered fishing boats.

\section{Other States' Practices in Southeast Asia}

Trawling fishery has been a favorite gears that used by fishermen all over the world. It is believed as the most efficient and effective gears to harvest shrimp and any bottom fisheries species ${ }^{18}$. Unfortunately, the usage of this gear has resulted severe damage in environment, not only dangerous for marine species such as turtle, but also to fisheries species which are not the targeted catch, since they will be returned to the sea mostly in dead or dying condition, identified as by-catch ${ }^{19}$.

Countries have different kind of practices in addressing this problem. Most of them are realized of this by-catch issue, but this problem is still pertaining in many regions, including in Europe, America, Australia and Asia. Even though many regulations have been made in various country relating to sustainable fisheries and conservation of marine environment, but there is still gap between practices and rules of law.

In Southeast Asian countries, shrimp as well as fish trawl is commonly used and among the major gears that used by fishermen, including in Malaysia, Indonesia, Thailand, Vietnam, and Philippines. The effectiveness of bottom trawling is difficult to challenge, it is the most efficient method to harvest shrimp as well as fish. That is why many countries have been trying to mitigate

\footnotetext{
${ }^{18}$ Report of the Regional Workshop for Latin America and the Carribean for Project EP/GLO/201/ GEF : Reduction of Environmental Impact from Tropical Shrimp Trawling through the Introduction of ByCatch Reduction Technologies and Change of Management, Trinidad and Tobago, 27-3- September 2004.

(ftp://ftp.fao.org/FI/DOCUMENT/rebyc/latin_america/Report_Workshop_2004.pdf)

${ }^{19}$ European Trawlers Are Destroying the Oceans

(http://www.oceana.org/fileadmin/oceana/uploads/europe/reports/european_trawlers_ destroying_oceans.pdf)
} 
the negative impact of trawl fishery as also supported by The FAO through GEF project. In Southeast Asia itself, there is a center called The Southeast Asian Fisheries Development Center which has developed a device called "Juvenile and Trash Excluder Devices (JTEDs) that is particularly use for fish trawl vessel. This device has been tried in several fishing zone such as in Provinces of Chumphon and Prachuap Kirikhan-Thailand, Arafura Sea-Indonesia, Alor SetarMalaysia and Manila Bay-Philippines ${ }^{20}$.

These experiments showed that JTED could be served as the appropriate devices to be used in trawl fishery, by choosing the correct device to suit target species and fishing grounds. Chokesanguan admitted that this device still needs further improvement and modification to be able to rectify the problem of bycatch in certain Southeast Asian countries ${ }^{21}$. as follows:

Certain regulations in Southeast Asian Countries relating to by-catch are

\section{A. Malaysia}

\section{Law of Malaysia Act 317 Fisheries Act 1985}

This Regulation contains measures in order to protect and to conserve marine environment in the Malaysian Fisheries Water especially related to the fishing operation. In this regulation, the Government rules the Preliminary plan of Fishing Operations; General Licensing of Fishing Operation; Regulations for Foreign Vessels to Fish in the Malaysian Fisheries Water, Punishment for Offences; and Development of inland Fisheries including conservation of Turtle and Aquaculture; and how to enforce this Regulation.

Article 6. Preparation of fisheries plans

(1) The Director-General shall prepare and keep under continual review fisheries plans based on the best scientific information available and designed to ensure optimum utilization of fishery resources, consistent with sound conservation and management principles and with avoidance of over fishing, and in accordance with the overall national policies, development plans and programs.

(2) Each plan and each modification or revision thereof shall be implemented after approval by the Minister.

(3) All development within the fisheries industry shall conform generally with the management and conservation policies described in the fisheries plans.

Article 9. Application for license or permit in respect of new fishing vessel

(1) An application for a license under this Part or for a permit under Part $\mathrm{V}$ in respect of any new fishing vessel shall be made to the DirectorGeneral before construction of the vessel is commenced, and shall be accompanied by such plans, specifications or other information as the Director-General may require or as may be prescribed in regulations made under this Act.

\footnotetext{
${ }^{20}$ www.apfic.org/modules/xfsection/download.php?fileid=39 -

${ }^{21}$ Ibid.
} 
(2) The applicant may proceed with the construction of the new fishing vessel upon receiving written approval so to do from the DirectorGeneral subject to such conditions, including conditions in respect of the horsepower, size and tonnage of the vessel, or disposal of any existing fishing vessel, as may be specified in the approval.

(3) The Director-General may refuse to issue a license in respect of any new fishing vessel which was not constructed with approval, and in accordance with the conditions specified, under subsection (2).

(4) Where under a fisheries plan it is provided that no license under this Part or permit under Part V shall be issued in respect of a new fishing vessel for a specified type of fisheries unless such new fishing vessel is in replacement of a fishing vessel already issued with such license or permit for such type of fisheries, the Director-General shall not issue a license or permit in respect of the new fishing vessel until the existing fishing vessel is disposed of in accordance with his directions.

Article 15.Fishing, etc., by foreign fishing vessel in Malaysian fisheries waters.

(2) No foreign fishing vessel shall load or unload any fish, fuel or supplies or transship in any fish Malaysian fisheries waters without the written approval of the Director General.

Article 18. Director-General to take account of certain matters in considering application for permit.

(1) The Director-General shall in considering an application for a permit under section 19 in respect of a foreign fishing vessel take into account the following matters:

(a) the needs of Malaysian fishermen and the provisions of the fisheries plans referred to in Part III;

(b) the extent of co-operation given and contributions made by the relevant country or relevant international organization towards fishery research, identification of fish stocks, the conservation, management and development of fishery resources within Malaysian fisheries waters, and compliance with the laws of Malaysia relating to such resources by the country or international organization;

(c) the assistance given by the applicant, relevant country or international organization in the development of the fishing industry on Malaysia, in the training of Malaysian personnel and the transfer of technology to the fishing industry of Malaysia;

(d) the terms of any relevant international fishery agreement in force; and

(e) the reciprocity of treatment given to local fishing vessels by the relevant country or relevant international organization.

25. Offences under Act.

Any person who contravenes or fails to comply with any provision of this Act shall be guilty of an offence and where no special penalty is provided in relation thereto, such person shall be liable- 
(a) where the vessel concerned is a foreign fishing vessel or the person concerned is a foreign national, to a fine not exceeding one million ringgit each in the case of the owner or master, and one hundred thousand ringgit in the case of every member of the crew;

(b) in all other cases, to a fine not exceeding twenty thousand ringgit or a term of imprisonment not exceeding two years or both.

38. Power of State Authority and Minister to make rules concerning turtles and inland Fisheries.

(1) The State Authority or, in respect of the Federal Territories of Kuala Lumpur and Labuan, the Minister may make rules specifically or generally for the proper conservation, development, management and regulation of turtles and inland fisheries in any State in Malaysia or in the Federal Territories of Kuala Lumpur and Labuan, as the case may be...

46. Powers of authorized officer.

For the purpose of ensuring compliance with the provisions of this Act, any authorized officer may where he has reason to believe that an offence has been committed under this Act, without a warrant-

(a) stop, board and search any vessel within Malaysian fisheries waters and make any enquiry, examination and inspection concerning the voyage and seaworthiness of that vessel, its crew, equipment or fishing appliance, or fish carried on board that vessel;

(b) stop, board and search, and inspect any vessel or vehicle transporting fish, whether within Malaysian fisheries waters or on land;

(c) require to be produced and examine any fishing appliance whether within Malaysian fisheries waters or on land;

(d) examine any fishing stakes, fish-aggregation device or marine culture system within Malaysian fisheries waters;

(e) inspect any license, permit, record, certificate or any other document required under this Act or under any generally accepted international rules and standards, and make copies of the same.

47. Powers of entry, seizure and arrest, etc.

(1) Any authorized officer may, where he has reason to believe that an offence has been committed under this Act, without a warrant-

(a) enter and search any place in which he has reason to believe that an offence under this Act is about to be or has been committed;

(b) take samples of any fish found in any vessel or vehicle inspected under section 46 or any place searched under paragraph (a);

(c) arrest any person who he has reason to believe has committed an offence under this Act;

(d) seize any vessel, including its equipment, gear, furniture, appurtenances, stores and cargo, or any vehicle which he has reason to believe has been used in the commission of any offence or in relation to which any offence has been committed under this Act; 
(e) seize any fish which he has reason to believe has been caught in the commission of an offence under this Act;

(f) seize any explosive, poison, pollutant, apparatus or prohibited gear which he has reason to believe has been used, or was in the possession of someone, in contravention of section 26; or

(g) seize any unlicensed fishing stakes, fishing appliance, fishaggregation device or marine culture system.

These above regulations mandates the authorized fisheries managers to develop fisheries plan based on the best scientific data (article 6) and maintain conservation of resources, and fishing license only could be issued under the scrutiny of needs and fisheries plans (article 9). This Law also governs the conservation of turtle (article 38) and the monitoring, controlling and surveillance (MCS) process.

\section{B. Thailand}

\section{Thailand Fisheries Act, B.E. 2490 (1947)}

This regulation regulates general fisheries operation in Thailand. It includes category of fishing operation; general licensing of fishing operation, the authority of Fishing operation, conservation and protection of marine environment, taxation from fishing operation, control of fishing operation, and penalties.

\section{Section 5}

The Minister of Agriculture shall take charge and control of the execution of this Act, and shall have the power to appoint competent official and to issue Ministerial Regulation fixing the rates of fishery taxes and fees not exceeding the rates in the Schedule annexed to this Act and determining other activities for carrying out this Act.

\section{Section 6:}

Fisheries are of four categories:
a. Preservation fisheries;
b. Leasable;
c. Reserved fisheries;
d. Public fisheries

\section{Section 7}

The provincial Council with the approval of the Minister, is empowered to make notification determining fisheries within their province to be in the category of preservation fisheries, leasable fisheries, or reserved fisheries.

\section{Section 25}

The Minister shall have the power to make a notification requiring person in any localities who engage in fishing, trading in aquatic animals, fishery products or fishery industry as may be specified in the Royal Decree to be registered, and 
requiring the to apply to the competent official for permission before engaging in such occupation with or without the license fee being charge under this Act.

\section{Section 28}

Any person is entitled to use licensed fishing implement only when the license specifying his name has been issued and the fishery tax under Act has been paid.

\section{Section 30}

Any person who is desirous of fishing in reserved fisheries must apply for permission and pay fishery tax under this Act. The money in respect of tendering payable by the licensee shall be deemed to be fishery tax under this Act.

\section{Section 52}

The provincial governor has the power, subject to the approval of the Minister, to make a notification forbidding any person other than the licensee to enter any fisheries unless permission has been obtained from the licensee or the competent official.

\section{Section 64}

Whoever uses fishing implement without license required by this Act under Section 28, or does not pay additional tax under Section 29 shall be punished with fine three times the amount of the tax and the Director-General or the competent official assigned by the Director General shall have the authority to impose fine.

It is interesting that Thailand has divided its fisheries into different categories which are preservation fisheries, leasable fisheries, reserved fisheries or public fisheries. This shows that Thailand also concerns on conservation of fisheries resources by defining preservation and reserved fisheries.

\section{Philippines}

\section{Republic Act No 8435}

An Act Prescribing Urgent Related Measure To Modernize the Agriculture and Fisheries Sectors of the Country in order to Enhance Their Profitability, and Prepare Said Sectors for the Challenges of Globalization through an Adequate, Focused and Rational Delivery of Necessary Support Services, Appropriating Funds Therefore and For Other Purposes.

This regulation governs the modernization of fisheries and agriculture technology.

\section{SEC. 13. Agricultural and Fisheries Modernization Plan (AFMP). -}

The Department, in consultation with farmers and fisher folk, the private sector, NGOs, people organizations people's organization and the appropriate government agencies and offices shall formulate and implement a medium and long-term comprehensive. Agriculture and Fisheries Modernization Plan.

The Agriculture and Fisheries Modernization Plan shall focus on five (5) major concerns: 

a. Food security;
b. Poverty alleviation and social equity;
c. Income enhancement and profitability, especially for farmers and fisher folk;
d. Global competitiveness; and
e. Sustainability

\section{Republic Act No 8550}

\section{The Philippines Fisheries Code of 1998}

This regulation governs fisheries done by its nationals. It regulates fishing license, catch ceiling limitations, protection and surveillance, the use of fishing devices, reportorial requirements, and violations.

It is important to note that under this fisheries law is mentioned the duty to protect endangered species. The authorized officer also has to observe the status of certain water, whether is still available for fishing or already over fishing, in over fished water the fisheries managers shall prohibit or limit fishing effort in this area.

\section{SEC. 5.Use of Philippine Waters -}

The use and exploitation of the fishery and aquatic resources in Philippine waters shall be reserved exclusively to Filipinos: Provided, however, that research and survey activities may be allowed under strict regulations, for purely research, scientific, technological and educational purposes that would also benefit Filipino citizens.

\section{SEC. 7. Access to Fishery Resources. -}

The Department shall issue such number of licenses and permits for the conduct of fishery activities subject to the limits of the MSY of the resource as determined by scientific studies or best available evidence. Preference shall be given to resource users in the local communities adjacent or nearest to the municipal waters.

\section{SEC. 8. Catch Ceiling Limitations. -}

The Secretary may prescribe limitations or quota on the total quantity of fish captured, for a specified period of time and specified area based on the best available evidence. Such a catch ceiling may be imposed per species of fish whenever necessary and practicable: Provided, however, that in municipal waters and fishery management areas, and waters under the jurisdiction of special agencies, catch ceilings may be established upon the concurrence and approval or recommendation of such special agency and the concerned LGU in consultation with the FARMC for conservation or ecological purposes.

\section{SEC. 11. Protection of Rare, Threatened and Endangered Species. -}

The Department shall declare closed seasons and take conservation and rehabilitation measures for rare, threatened and endangered species, as it may determine, and shall ban the fishing and/or taking of rare, threatened and/or endangered species, including their eggs/offspring as identified by existing laws in concurrence with concerned government agencies. 
SEC. 14. Monitoring, Control and Surveillance of Philippine Waters. -

A monitoring, control and surveillance system shall be established by the Department in coordination with LGUs, FARMCs, the private sector and other agencies concerned to ensure that the fisheries and aquatic resources in Philippine waters are judiciously and wisely utilized and managed on a sustainable basis and conserved for the benefit and enjoyment exclusively of Filipino citizens.

\section{SEC. 23. Limited Entry Into Over fished Areas.}

Whenever it is determined by the LGUS and the Department that a municipal water is over fished based on available data or information or in danger of being over fished, and that there is a need to regenerate the fishery resources in that water, the LGU shall prohibit or limit fishery activities in the said waters.

\section{SEC. 26. Commercial Fishing Vessel License and Other Licenses. -}

No person shall operate a commercial fishing vessel, pearl fishing vessel or fishing vessel for scientific, research or educational purposes, or engage in any fishery activity, or seek employment as a fish worker or pearl driver without first securing a license from the Department, the period of which shall be prescribed by the Department: Provided, that no such license shall be required of a fishing vessel engaged in scientific research or educational purposes within Philippine waters and pursuant to an international agreement of which the Philippines is a signatory and which agreement defines the status, privileges and obligations of said vessel and its crew and the non-Filipino officials of the international agency under which vessel operates: Provided, further, that members of the crew of a fishing vessel used for commercial fishing except the duly licensed and/ or authorized patrons, marine engineers, radio operators and cooks shall be considered as fisher folk: Provided, furthermore, that all skippers/master fishers shall be required to undertake an orientation training on detection of fish caught by illegal means before they can be issued their fish worker licenses: Provided, finally, that the large commercial fishing vessel license herein authorized to be granted shall allow the licensee to operate only in Philippine waters seven (7) or more fathoms deep, the depth to be certified by the NAMRIA, and subject to the conditions that may be stated therein and the rules and regulations that may be promulgated by the Department.

\section{SEC. 38. Reportorial Requirements. -}

Each commercial fishing vessel shall keep a daily record of fish catch and spoilage, landing points, and quantity and value of fish caught, and off-loaded for transshipment, sale and/or other disposal. Detailed information shall be duly certified by the vessel's captain and transmitted monthly to the officer or representative of the Department, at the nearest designated landing point.

\section{SEC. 51. License to Operate Fish Pens, Fish Cages, Fish Traps and Other Structures} for the Culture of Fish and Other Fishery Products. -

Fish pens, fish cages, fish traps and other structures for the culture of fish and other fishery products shall be constructed and shall operate only within established zones duly designated by LGUs in consultation with the FARMCs concerned consistent with national fisheries policies after the corresponding 
licenses thereof have been secured. The area to be utilized for this purpose for individual person shall be determined by the LGUs in consultation with the concerned FARMC: Provided, however, That not over ten percent $(10 \%)$ of the suitable water surface area of all takes and rivers shall be allotted for aquaculture purpose like fish pens, fish cages and fish traps; and the stocking density and feeding requirement which shall be controlled and determined by its carrying capacity: Provided further, That fish pens and fish cages located outside municipal waters shall be constructed and operated only within fish pen and fish cage belts designated by the Department and after corresponding licenses therefore have been secured and the fees thereof paid.

\section{SEC. 86. Unauthorized Fishing or Engaging in other Unauthorized Fisheries}

\section{Activities. -}

No person shall exploit, occupy, produce, breed, culture, capture or gather fish, fry or fingerlings of any fishery species or fishery products, or engage in any fishery activity in Philippine waters without a license, lease or permit.

SEC. 92. Ban on Muro-Ami, Other Methods and Gear Destructive to Coral Reefs and Other Marine Habitat. - It shall be unlawful for any person, natural or juridical, to fish with gear method that destroy coral reefs, sea grass beds, and other fishery marine life habitat as may be determined by the Department. "Muro-Ami" and any of its variation, and such similar gear and methods that require diving, other physical or mechanical acts to pound the coral reefs and other habitat to entrap, gather or catch fish and other fishery species are also prohibited.

\section{SEC. 101. Violation of Catch Ceilings. -}

It shall be unlawful for any person to fish in violation of catch ceilings as determined by the Department. Violation of the provision of this section shall be punished by imprisonment of six (6) months and one (1) day to six (6) years and/or a fine of Fifty Thousand Pesos (P50,000.00) and forfeiture of the catch, and fishing equipment used and revocation of license.

Learning those above regulations makes it clear that those Southeast Asian Countries have realized that fishery should be managed in sustainable manner and that including by governing fishery and mitigating its by-catch problems.

\section{Conclusion}

Based on above findings, some conclusions regarding sustainable fisheries, especially in Indonesia could be drawn as follows:

1. Indonesia has actually had certain policy regarding trawling practices, it is however has not been effectively practiced since the supervision and enforcement have not been effective due to several reasons, such as the insufficient patrol ship and legal enforcers;

2. Indonesia needs to impose sustainable fisheries, not only because it is required by the importing countries such as USA, but more because the 
principle of sustainable fisheries resources utilization as adopted in the Indonesian Law on Fisheries (Law No. 31 Year 2004 as amended by Law No. 45 Year 2009);

3. The autonomy law has given great responsibility to the regional government in enacting its own policy and regulation regarding the utilization of marine living resources, including fish and other creatures. This policy and regulation however should be in line with the central government/national policy and regulation;

4. There is insufficient data that could show how the trawl practices in Indonesia are and how the regional government has behaved in addressing the trawling fishery and its by-catch

5. Any applicable practices or rules in other countries or organization could be taken as a lesson learned for Indonesia to achieve effective and efficient policy and implementation plan as well as enforcement tool on reducing by-catch in fishing, thus the sustainable fisheries could be achieved in order to guard Indonesia's national interest.

\section{Bibliography}

\section{Regulation}

Law No. 32 Year 2004

Minister of Agriculture Decree No. 392 Year 1999 on Fishing Zone.

\section{Book}

Buck, Susan J., The Global Commons: An Introduction,1998.

\section{Journal Article}

Knight, Maurice and Kem Lowry, "Institutional Arrangements for Decentralized Coastal Management in Indonesia", paper presented at "The Challenges of Public for Sustainable Ocean and Coastal Development", Global Conference on Oceans and Coasts at Rio, December 10, 2001, Paris, France.

\section{Conventions / International Agreements / International Decisions}

Agreement for the Implementation of the Provisions of the United Nations Convention on the Law of the Sea of 10 December 1982 Relating to the Conservation and Management of Straddling Stocks, 1995 (1995 UN Fish Stocks Agreement)

Agreement to Promote Compliance with the International Conservation and Management Measures by Fishing Vessels on the High Seas, 1993 (1993

FAO Compliance Agreement).

Document of the Project "Reduction of Environmental Impact From Tropical Shrimp Trawling Through the Introduction of By-Catch Reduction Technologies and Change of Management" (EP/GLO/201/GEF). 
FAO Fisheries Department, The Ecosystem Approach to Fisheries," FAO Technical Guidelines for Responsible Fisheries, No. 4, Suppl.2., Rome, FAO, 1 (2003).

\section{Digital References}

ftp://ftp.fao.org/FI/DOCUMENT/rebyc/latin_america/Report_ Workshop_2004.pdf

http://www.apfic.org/modules/xfsection/download.php?fileid=39

http://www.fao.org/documents/show_cdr.asp?url_file=/DOCREP/005/ v9878e/v9878e00.htm

http://www.johannesburgsummit.org/html/basic_info/unced.html http://www.oceana.org/fileadmin/oceana/uploads/europe/reports/ european_trawlers_destroying_oceans.pdf 